\title{
EXPERIMENTS AND SIMULATIONS ON DAY-TO-DAY ROUTE CHOICE-BEHAVIOUR
}

\author{
R. SELTEN \\ M. SCHRECKENBERG \\ T. PITZ \\ T. CHMURA \\ S. KUBE
}

CESIFO WORKING PAPER NO. 900

CATEGORY 10: EMPIRICAL AND THEORETICAL METHODS

APRIL 2003 


\title{
EXPERIMENTS AND SIMULATIONS ON DAY-TO-DAY ROUTE CHOICE-BEHAVIOUR
}

\begin{abstract}
The paper reports laboratory experiments on a day-to-day route choice game with two routes. Subjects had to choose between a main road $M$ and a side road $S$. The capacity was greater for the main road. 18 subjects participated in each session. In equilibrium the number of subjects is 12 on $M$ and 6 on $S$.

Two treatments with 6 sessions each were run at the Laboratory of Experimental Economics at Bonn University using RatImage. Feedback was given in treatment I only about own travel time and in treatment II on travel time for $M$ and $S$. Money payoffs increase with decreasing time. The main results are as follows.

1. Mean numbers on $M$ and $S$ are very near to the equilibrium.

2. Fluctuations persist until the end of the sessions in both treatments.

3. Fluctuations are smaller under treatment II .The effect is small but significant.

4. The total number of changes is significantly greater in treatment $\mathrm{I}$.

5. Subjects' road changes and payoffs are negatively correlated in all sessions.

6. A direct response mode reacts with more changes for bad payoffs whereas a contrary response mode shows opposite reactions. Both response modes can be observed.

7. The simulation of an extended payoff sum learning model closely fits the main results of the statistical evaluation of the data.
\end{abstract}

JEL Code: C91, C92, C15, L91, R4.

Keywords: travel behaviour research, information in intelligent transportation systems, dayto-day route choice, laboratory experiments, payoff sum model.

Reinhard Selten

Laboratory of Experimental Economics

Adenauerallee 24-42

53113 Bonn

Germany

rselten@wiwi.uni-bonn.de
M. Schreckenberg

Physics of Transport and Traffic

Gerhard Mercator University

Lotharstr. 1

47048 Duisburg

Germany

\author{
T. Pitz - T. Chmura - S. Kube \\ Laboratory of Experimental Economics \\ Adenauerallee 24-42 \\ 53113 Bonn \\ Germany
}

We are grateful to the BMBF for financial support. 


\section{Introduction}

Understanding individual travel behaviour is essential for the design of Advanced Traveller Information Systems (ATIS), which provide real-time travel information, like link travel times (Adler AND Blue 1998, BARFIELD AND Dingus 1998). However, the response of road users to information is still an open question (E.G., BEN-AKIVA 1991, BONSALL 1992, MAHMASSANI AND LIU 1999). It is not clear whether more information is beneficial (BEN-AKIVA ET AL. 1991). Drivers confronted with too much information may become oversaturated in the sense that information processing becomes to difficult and users develop simple heuristics to solve the problem (GIGERENZER ET AL. 1999).

Drivers may also overreact to information and thereby cause additional fluctuations. Thus, the behaviour of the drivers has to be incorporated in the forecast (e.g. WAHLE ET AL. 2000, BENAKIVA ET AL. 1991, BonSALL 1992). ATIS can reduce fluctuations only if behavioural effects are correctly taken into account.

The Literature reports a number of experiments on route choice behaviour (e.g. BonSALL 1992, MAHMASSANI AND LIU 1999). Here we focus on the route choice in a generic two route scenario, which already has been investigated in the literature (e.g. IIDA ET AL. 1992). However our aim is to present experiments with a large number of periods and with sufficiently many independent observations for meaningful applications of non-parametric significance tests. 
If one wants to investigate results of day to day route choice which can be transferred to more realistic environments, it is necessary to explore individual behaviour in an interactive experimental set-up. Does behaviour converge to equilibrium? Does more feedback reduce fluctuations? What is the structure of individual responses to recent experiences? Our experimental study tries to throw light on these questions.

\section{Experimental Set-Up}

Subjects are told that in each of 200 periods they have to make a choice between a main road $M$ and a side road $S$ for travelling from A to B.

main road



side road

Figure 1: Participants had to choose between a side road [S] and a main road [M]

They were told that $M$ is faster if $M$ and $S$ are chosen by the same number of people. The number of subjects in each session was 18 , mostly law and economic students from the University of 
Bonn. The time $t_{M}$ and $t_{S}$ depends on the numbers $n_{M}$ and $n_{S}$ of participants choosing $M$ and $S$, respectively:

$$
\begin{aligned}
& t_{M}=6+2 n_{M} \\
& t_{S}=12+3 n_{S} .
\end{aligned}
$$

The period payoff was $40-t$ with $t=t_{M}$ if $M$ was chosen and $t=t_{S}$ if $S$ was chosen.

The total payoff of a subject was the sum of all 200 period payoffs converted to money payoffs in DM with a fixed exchange rate of .015 DM for each experimental money unit (Taler). Additionally, every participant received a lump sum payment of 200 Taler and a show- up fee of $10 \mathrm{DM}$. One session took roughly one and a half hours.

All pure equilibria of the game are characterized by

$$
n_{M}=12 \text { and } n_{S}=6 \text {, }
$$

resulting in a period payoff of 10 Taler per player. This sums up to 180 Taler per period, differing from the pareto-optimum with 181 Taler. The pareto-optimum can be reached by

$$
n_{M}=11 \text { and } n_{S}=7 \text {. }
$$

Two treatments have been investigated. In treatment I the subjects received:

- travel time of the last chosen route

- last chosen route

- payoff of the last period in Taler 
- cumulated payoff in Taler

- number of the actual period

In treatment II additional feedback was provided about the travel time on the non-chosen-route in the last period. Six sessions were run with treatment I and six with treatment II. No further information was given to the subjects.

\section{Equilibrium Predictions and Observed Behaviour}

\subsection{Number of players on the side road $S$}

Figure 2 shows the number of participants on the side road $S$ as a function of time for a typical session of treatment I.

It can be seen that there is no convergence to the theoretical equilibrium. There are substantial fluctuations until the end of the session. The same is true for all sessions of both treatments. The overall average of numbers of participants on $S$ is very near to the equilibrium prediction. In each session the median number of players on the side road $S$ is 6 . The mean number of players on the side road $S$ is 5.98 in treatment I and 6.06 in treatment II. The standard deviation of the session average from 6 is never greater than .17 and it is only .07 on the average. The fluctuations can be measured by the standard deviation of the number of participants choosing $S$ per period. This 
standard deviation is between 1.53 and 1.94. In view of these numbers one can speak of substantial fluctuations in each of the 12 sessions.

The fluctuations are a little larger under treatment I than under treatment II. The effect is significant. The null-hypothesis is rejected by a Wilcoxon-Mann-Whitney-Test on the significance level of $5 \%$ (one sided).

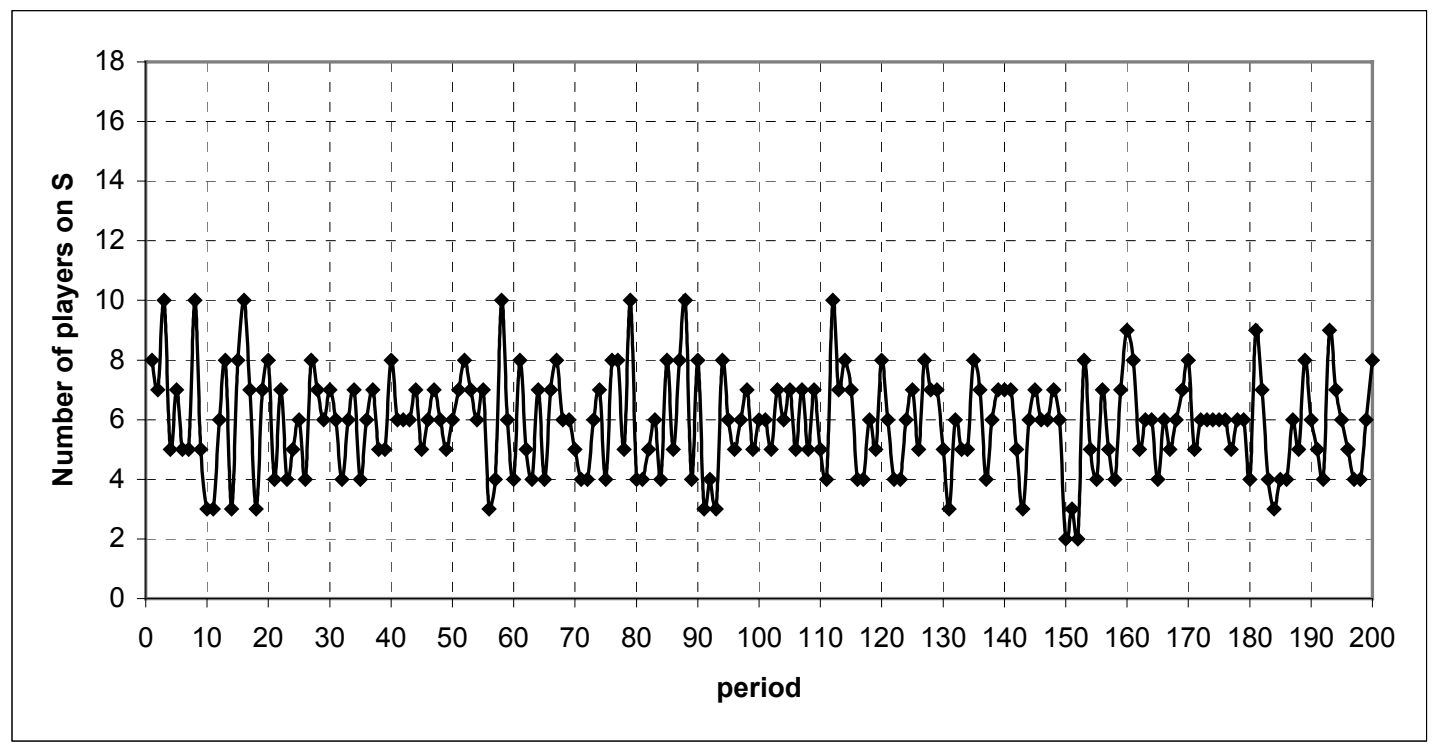

Figure 2: Number of participants on $S$ [a typical session of treatment I].

The game underlying the experiment has many pure strategy equilibrium points. In all of them the number of participants on the side road is 6 , but the set of players who choose $S$ can be any set of 6 players. The multiplicity of pure strategy equilibria poses a coordination problem which may be one of the reasons for non-convergence and the persistence of fluctuations. Feedback on 
both travel times vs. feedback on only own travel time has a beneficial effect by the reduction of fluctuations, but this effect is relatively small.

\subsection{Road changes}

Figure 3 shows an example of the number of road changes as a function of time for a typical session of treatment I.

\begin{tabular}{|c|c|c|c|}
\hline & & \multicolumn{2}{|c|}{ number of players on $\mathrm{S}$} \\
\hline & & mean & std. dev. \\
\hline \multirow{7}{*}{ 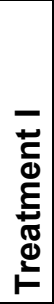 } & session I 01 & 6,02 & 1,814 \\
\hline & session I 02 & 5,91 & 1,691 \\
\hline & session I 03 & 6,01 & 1,849 \\
\hline & session I 04 & 5,85 & 1,748 \\
\hline & session I 05 & 6,1 & 1,81 \\
\hline & session I 06 & 6,03 & 1,793 \\
\hline & treatment I & 5,98 & 1,784 \\
\hline \multirow{7}{*}{ 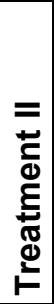 } & session II 01 & 5,98 & 1,64 \\
\hline & session II 02 & 6,05 & 1,584 \\
\hline & session II 03 & 5,99 & 1,53 \\
\hline & session II 04 & 6,1 & 1,935 \\
\hline & session II 05 & 6,06 & 1,631 \\
\hline & session II 06 & 6,17 & 1,692 \\
\hline & treatment II & 6,06 & 1,669 \\
\hline
\end{tabular}

Table 1: Mean and standard deviation of the number of players on S.

There was a negative trend in each session of treatment II. By comparison in treatment I there were two sessions with a positive, two with a negative and two with an indifferent trend.

The fluctuations are connected to the total number of road changes within one session. 
The Spearman-rank-correlation between the total number of road changes and the standard deviation of the number of participants per period on $\mathrm{S}$ is .795. This is significant on the level of $1 \%$ (one sided). The median number of road changes is significantly higher in treatment I. The null-hypothesis is rejected by the Wilcoxon-Mann-Whitney-Test on a level of $5 \%$ (one sided). The mean number of road changes under treatment I is also higher than under treatment II. A Wilcoxon-Mann-Whitney-Test rejects the null-hypothesis only on a very weak significance level of $8.98 \%$ (one sided).

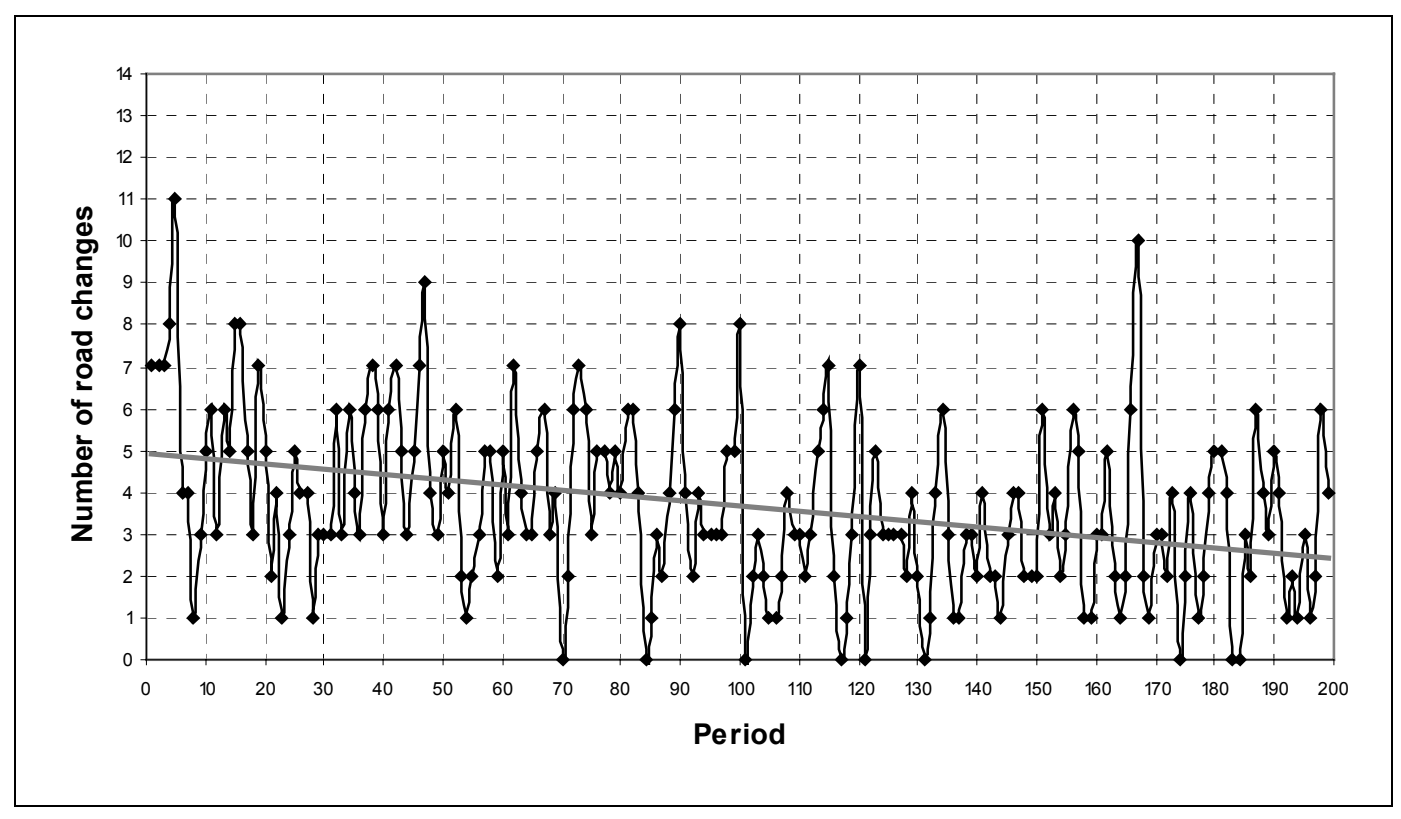

Figure 3: Number of road changes [a typical session of treatment I].

Under treatment I subjects who mainly choose only one of the roads feel the need to travel on the other road from time to time in order to get information on both roads. Under treatment II there is 
no necessity for such information gathering. This seems to be the reason for the greater number of changes and maybe also for the stronger fluctuations under treatment I.

\begin{tabular}{|c|c|c|c|}
\hline & & \multicolumn{2}{|c|}{ number of road changes } \\
\hline & & mean & std. dev. \\
\hline \multirow{7}{*}{ 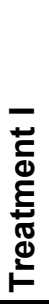 } & session I 01 & 5,08 & 2,298 \\
\hline & session I 02 & 3,87 & 1,865 \\
\hline & session I 03 & 5,16 & 1,934 \\
\hline & session I 04 & 5,19 & 1,931 \\
\hline & session I 05 & 5,28 & 2,391 \\
\hline & session I 06 & 4,35 & 2,083 \\
\hline & treatment I & 4,82 & 2,084 \\
\hline \multirow{7}{*}{ 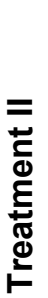 } & session II 01 & 3,99 & 2,001 \\
\hline & session II 02 & 3,68 & 2,039 \\
\hline & session II 03 & 3,67 & 2,091 \\
\hline & session II 04 & 5,19 & 2,32 \\
\hline & session II 05 & 4,67 & 2,48 \\
\hline & session II 06 & 4,44 & 2,044 \\
\hline & treatment II & 4,27 & 2,163 \\
\hline
\end{tabular}

Table 2: Mean and standard deviation of the number of road changes

\subsection{Payoffs}

The mean payoffs per period in treatment I were significantly lower than in treatment II. The standard deviation of this random variable was higher in treatment I than in treatment II. In both cases a Wilcoxon-Mann-Whitney-Test rejects the null-hypothesis on a significance level of $5 \%$ 
(one sided). Nevertheless the efficiency with regard to the pareto optimum was in treatment I .91 and in treatment II .92. The payoffs are shown in Table 3 and 4.

\begin{tabular}{|c|c|c|c|c|c|c|c|}
\hline \multicolumn{8}{|c|}{ Payoff 200 Periods [Treatment I] } \\
\hline & 101 & 102 & 103 & 104 & 105 & 106 & I \\
\hline mean & 9,10 & 9,18 & 9,06 & 9,10 & 9,13 & 9,12 & 9,11 \\
\hline std. dev. & 4,26 & $\overline{3,94}$ & 4,34 & 4,08 & 4,27 & 4,26 & 4,19 \\
\hline median & 10 & 10 & 10 & 10 & 10 & 10 & \\
\hline mode & 10 & 10 & 10 & 10 & 10 & 10 & \\
\hline $\min$ & -5 & -2 & -8 & -8 & -8 & -11 & \\
\hline $\max$ & 25 & 22 & 22 & 22 & 22 & 25 & \\
\hline
\end{tabular}

Table 3: Mean payoffs in Treatment I.

\begin{tabular}{|l|r|r|r|r|r|r|r|r|}
\hline Payoff 200 Periods [Treatment II] \\
\hline & II 01 & II 02 & II 03 & II 04 & II 05 & II 06 & II \\
\hline mean & 9,25 & 9,32 & 9,35 & 8,99 & 9,28 & 9,26 & 9,24 \\
\hline std. dev. & 3,80 & 3,77 & 3,60 & 4,58 & 3,85 & 4,03 & 3,94 \\
\hline median & 10 & 10 & 10 & 10 & 10 & 10 & \\
\hline mode & 10 & 10 & 10 & 10 & 10 & 10 & \\
\hline min & -2 & -5 & -2 & -17 & -2 & -5 & \\
\hline max & 22 & 22 & 22 & 28 & 22 & 25 & \\
\hline
\end{tabular}

Table 4: Mean payoffs in Treatment II.

One might see that the information about the travel time on both routes effects only a small difference concerning the payoffs.

\subsection{Payoffs and road changes}

In all sessions the number of road changes of a subject is negatively correlated with the subject's payoff. Figure 4 shows that the negative correlation between the payoff in treatment II is stronger than in treatment I. 

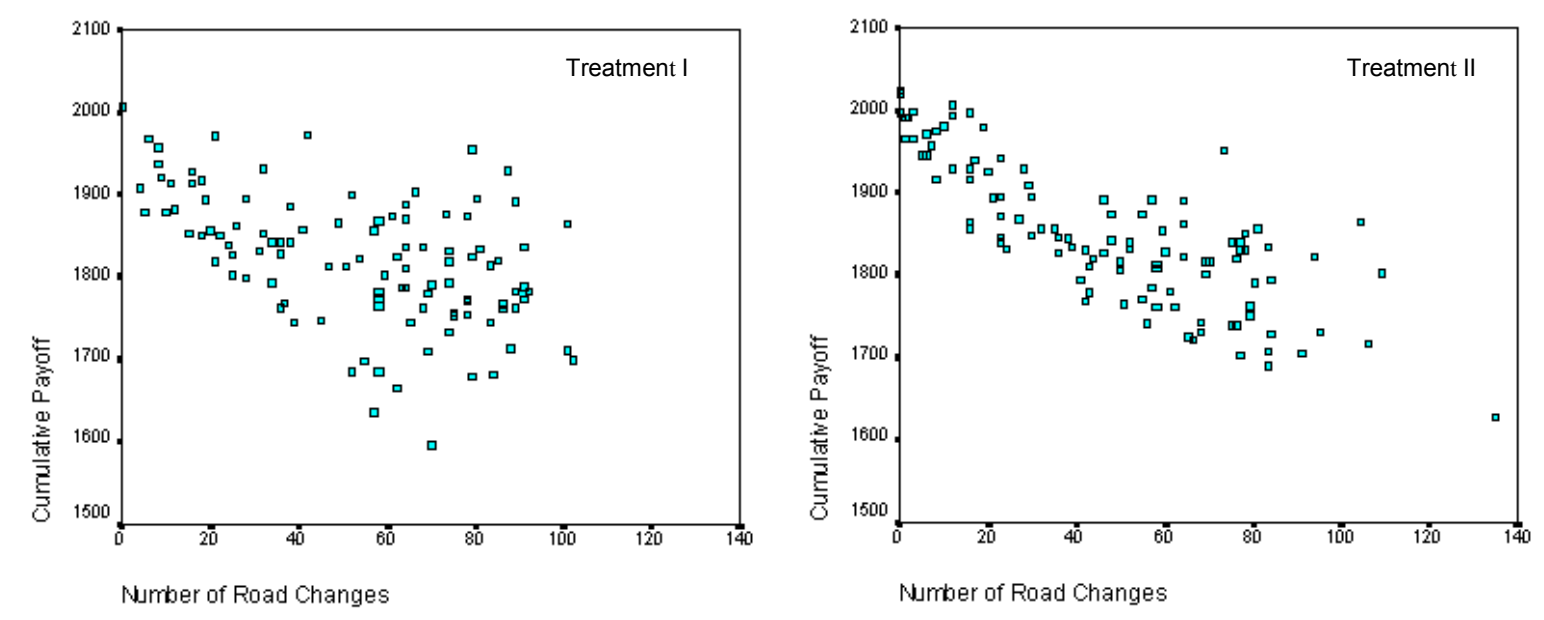

Figure 4: Scatter diagram cumulative payoff/number of road changes for treatment I and II.

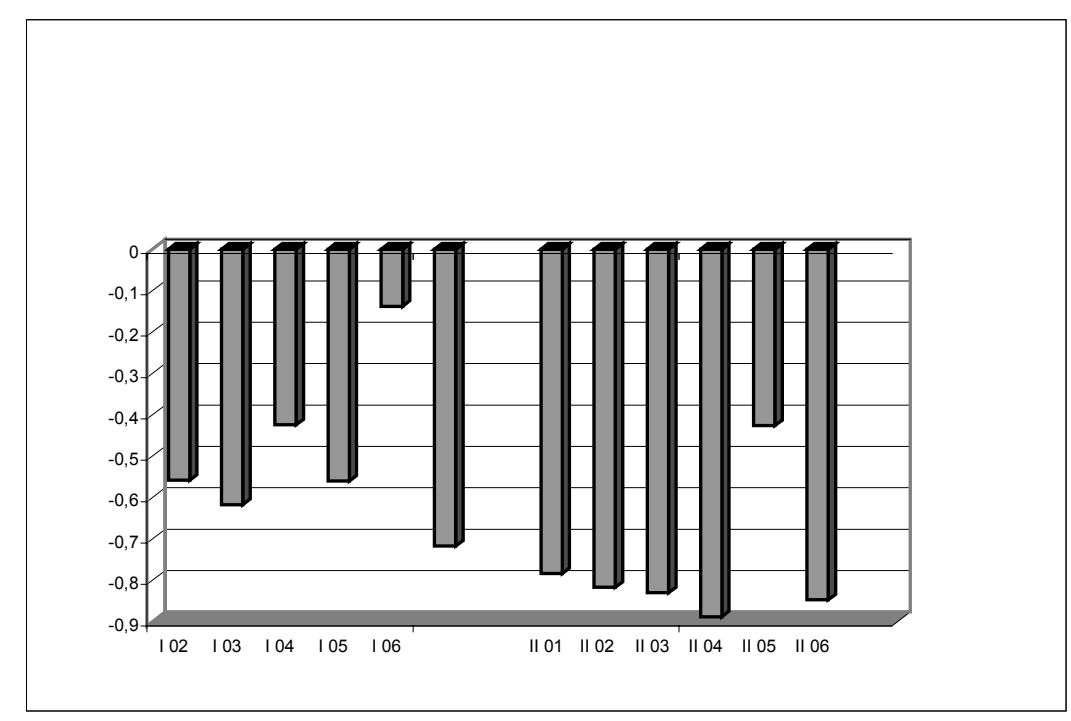

Figure 5: Spearmen rank correlation between cumulative payoffs and the number of road changes for each session of treatment I and II.

In both treatments the Spearman rank correlations between cumulative payoffs and the number of road changes are strictly negative. The Spearman-correlation-coefficients in treatment II are 
lower than in treatment I. A Wilcoxon-Mann-Whitney-Test rejects the null-hypothesis on a significance level of $5 \%$ (one sided). It is observed that some players in treatment I get an above average payoff even though they have a high change rate. The reason why this effect is not so often observed in treatment II might be, that the additional information about the travel time of the non chosen route was given. So it is not necessary for players to change in order to collect information. This might explain, that 3 players always stayed on the main road in treatment II, nevertheless it is surprising that one player did the same in treatment I.

Even if subjects change roads in order to get higher payoffs, they do not succeed in doing this on the average. This suggests that it is difficult to use the information provided by the feedback to one's advantage.

\section{Response mode}

A participant who had a bad payoff on the road chosen may change his road in order to travel where it is less crowded. We call this the direct response mode. A road change is the more probable the worse the payoff was.

The direct response mode is the prevailing one but there is also a contrarian response mode. Under the contrarian response mode a road change is more likely the better the payoff was. The 
contrarian participant expects that a high payoff will attract many others and that therefore the road chosen will be crowded in the next period.

The equilibrium payoff is 10 . Payoffs perceived as bad tend to be below 10 and payoffs perceived as good tend to be above 10. Accordingly we classified the response of a subject as direct if the road is changed after a payoff smaller than 10 or not changed after a payoff greater than 10 . An opposite response is classified as contrarian. Table 2 shows the numbers of times in which a subject changes roads (c. for a payoff below 10 and $\mathrm{c}_{+}$for a payoff above 10), or stays at the same road ( $s_{-}$for a payoff below 10 and $s_{+}$for a payoff above 10).

\begin{tabular}{|c|c|c|}
\hline & change & stay \\
\hline payoff $<\mathbf{1 0}$ & $c_{-}$ & $S_{-}$ \\
\hline payoff $>\mathbf{1 0}$ & $c_{+}$ & $S_{+}$ \\
\hline
\end{tabular}

Table 5: 2x2 table for the computation of Yule coefficients.

For each subject such a $2 \times 2$ table has been determined and a Yule coefficient $Q$ has been computed as follows.

$$
Q=\frac{c_{-} \cdot S_{+}-c_{+} \cdot S_{-}}{c_{-} \cdot S_{+}+c_{+} \cdot S_{-}}
$$

The Yule coefficient has a range from -1 to +1 . In our case a high Yule coefficient reflects a tendency towards direct responses and a low one a tendency towards contrarian responses. 
In each of four sessions, one of them in Treatment I and three in treatment II, there was one player for whom no Yule coefficient could be determined since these four subjects never change roads. These subjects are not considered in the evaluation of Yule coefficients.

The mean and the standard deviation of the Yule coefficients are shown in Table 6.

\begin{tabular}{|c|c|c|c|}
\hline & & \multicolumn{2}{|c|}{ Yule coefficients $\mathbf{Q}$} \\
\hline & & mean & std. dev. \\
\hline \multirow{7}{*}{ 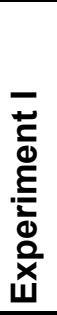 } & session I 01 & 0,214 & 0,654 \\
\hline & session I 02 & 0,373 & 0,592 \\
\hline & session I 03 & 0,277 & 0,525 \\
\hline & session I 04 & 0,191 & 0,603 \\
\hline & session I 05 & 0,313 & 0,584 \\
\hline & session I 06 & 0,332 & 0,542 \\
\hline & treatment I & 0,283 & 0,585 \\
\hline \multirow{7}{*}{ 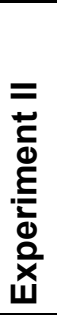 } & session II 01 & 0,365 & 0,591 \\
\hline & session II 02 & 0,374 & 0,536 \\
\hline & session II 03 & 0,308 & 0,552 \\
\hline & session II 04 & 0,271 & 0,584 \\
\hline & session II 05 & 0,246 & 0,738 \\
\hline & session II 06 & 0,122 & 0,557 \\
\hline & treatment II & 0,281 & 0,597 \\
\hline
\end{tabular}

Table 6: Mean and standard deviation of the Yule coefficients in both treatments.

Evidence for the importance of both response modes can be found in the distributions of Yule coefficients within a session. If the two response modes were not present in behaviour one would expect distributions of Yule coefficients concentrated around 0 . However the number of subjects with extreme Yule coefficients below -.5 or above +.5 tends to be greater than the number of subjects with Yule coefficients in the middle range between -.5 and +.5 . A Wilcoxon one sample 
test supports this alternative hypothesis by rejecting the null-hypothesis that none of both numbers tends to be greater than the other, on the significance level of $1 \%$ (two sided).

If one classifies subjects with Yule coefficients above +.5 as direct responders and subjects with Yule coefficients below -.5 as contrarian responders, then one receives $44 \%$ direct responders, $14 \%$ contrarian responders and $42 \%$ unclassified subjects. The distribution of the Yule coefficients is shown in figure 6 .

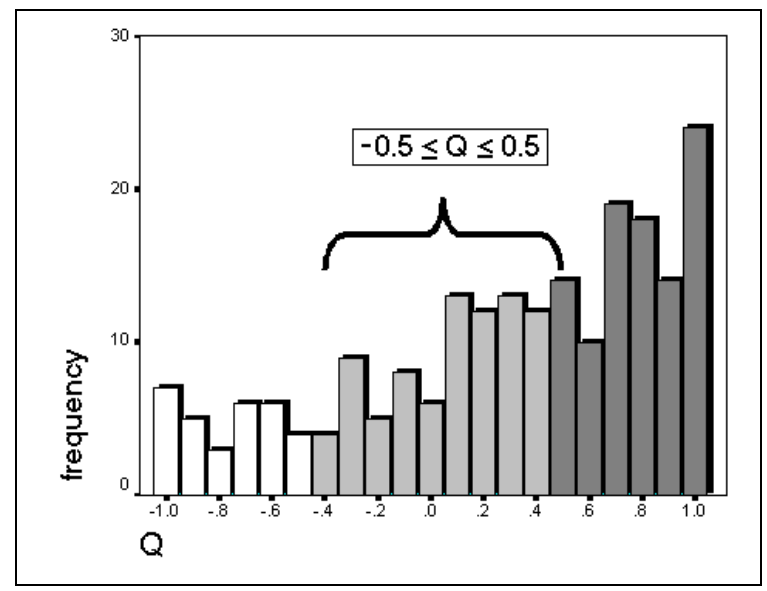

Figure 6: Distribution of the experimental Yule coefficients:

\section{Simulations}

In order to get more insight into this theoretical significance of our result, we have run simulations based on a version of a well known reinforcement learning model, the payoff-sum 
model. This model already described by Harley (1981) and later by Arthur (1991) has been used extensively by Ereth and Roth (1995) in the experimental economics literature.

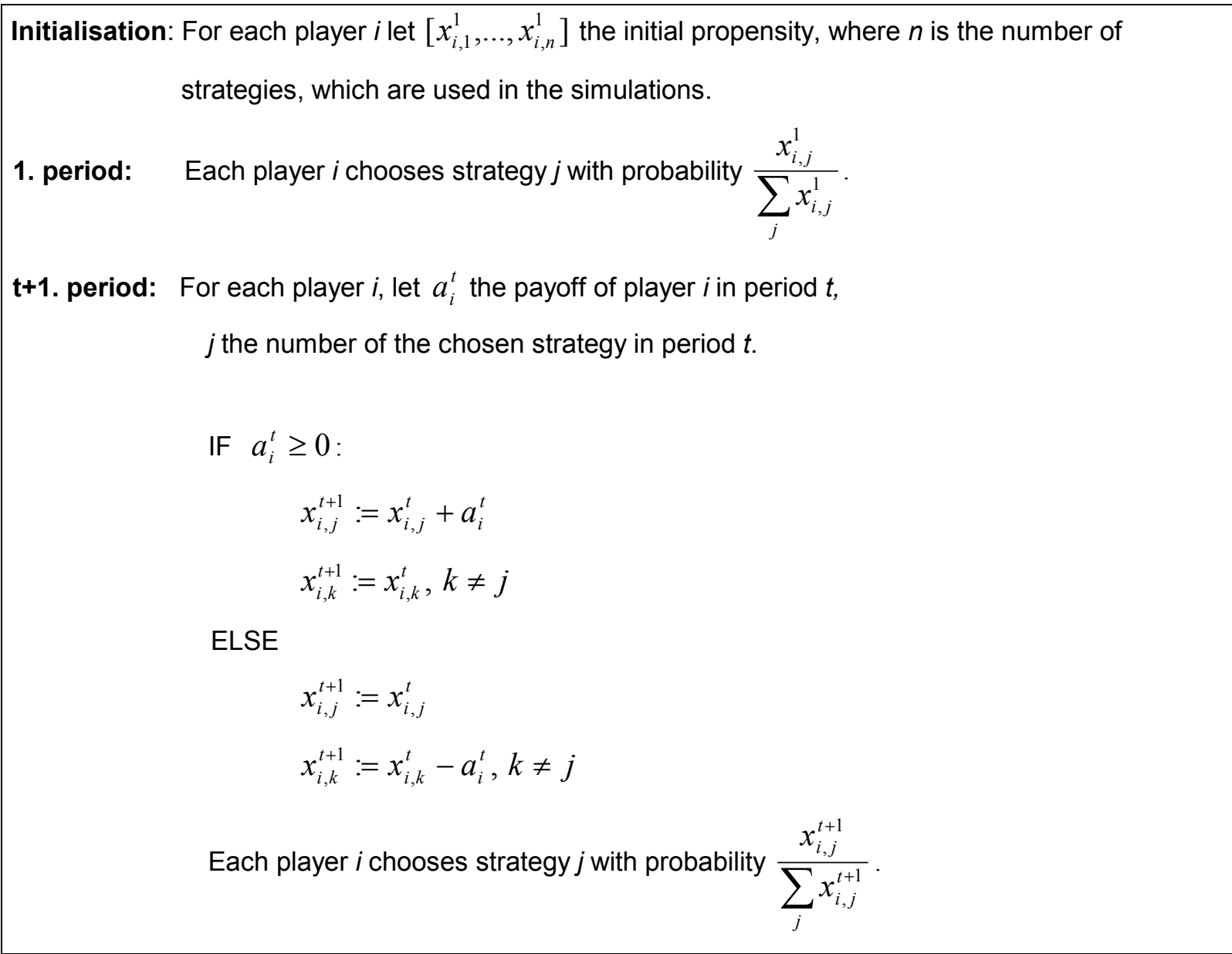

Table 7: The Payoff-Sum Model

Table 7 explains the version underlying our simulations. - We are looking at player $i$ who has to choose among $n$ strategies $1, \ldots, n$ over a number of periods $t, t=1 . . T$. The probabilities with which each strategy $i$ is chosen is proportional to its "propensity" $x_{i, j}^{t}$. In period 1 these propensities are 
exogenously determined parameters. Whenever the strategy $j$ is used in period $t$, the resulting payoff $a_{i}^{t}$ is added to the propensity if this payoff is positive. If all payoffs are positive, then the propensity is the sum of all previous payoffs for this strategy plus its initial propensity. Therefore one can think of a propensity as a payoff sum.

In our experiments negative payoffs are not impossible. This creates a difficulty for the model, since one has to exclude the case that a propensity becomes negative. In the literature this is sometime solved by adding up the exponential of the payoffs instead of the payoffs themselves. Here we take another approach to this problem. If a negative payoff is obtained for the use of the strategy $\mathrm{x}_{\mathrm{i}}$, the absolute value of this payoff is added to all other propensities and the propensity of the strategy i remains unchanged. We think that this is the simplest generalisation of the original payoff sum model which was conceived for positive payoffs only.

In our simulations 18 players interact for 200 periods just like in our experiments. Each player has four strategies:

1. main road:

This strategy simply consists in taking the decision for the main road.

2. side road:

This strategy consists in taking the side road.

\section{3. direct:}

This strategy corresponds to the direct response mode. The payoff of a player is compared to his median payoff among his payoffs for all periods up to now. If the present payoff is 
lower then this median payoff, then the road is changed. If the payoff is greater than this median payoff, the player stays on the same road as before. It may also happen that the current payoff is equal to the median payoff. In this case, the road is changed if the number of previous payoffs above the median is greater than the number of previous payoffs below the median. In the opposite case, the road is not changed. In the rare cases where both numbers are equal, the road is changed with probability $1 / 2$.

\section{4. contrarian:}

A player who takes this strategy stays on the last chosen road if his current payoff is smaller then the median payoff among the payoffs for all previous periods and he changes the road in the opposite case. If the current payoff is equal to this median payoff, then he changes the road if the number of previous payoff below the median payoff is greater then the number above the median payoff. If the numbers of previous payoff below and above the median payoff are equal, the road is changed with probability $1 / 2$.

In the first period only strategy one and two were available to the simulated subjects since strategy three and four cannot be applied because there is not yet a median of previous payoffs.

The strategies direct and contrarian describe the response modes discussed in section 4, but with a small difference. There changing and staying was conditioned on how the last payoff differed from the equilibrium payoff 10. In the experiments the median payoff is very often at 10 . However, in the simulations we did not want to build in prejudices based on theoretical values. 
Our simulated players base their behaviour on initial propensities and observations only. Of course, it is assumed that as in the experiments the players get feedback about their own payoffs immediately after their choices. In the experimental treatment II additional feedback about the payoff on the route not chosen was given. The payoff sum model makes use of a player's own payoff only and therefore ignores the additional feedback of treatment II.

The differences between treatment I and treatment II cannot be explained by the payoff sum model since it does not process the additional feedback information given in treatment II. For the purposes of comparing our simulation data with the experimental data we ignore the differences between treatment I and II which are not big anyhow.

The difficulty arises that the initial propensities must be estimated from the data. We did this by varying the initial propensities for the strategies main road and side road over all integer values from 1 to 10 and the initial propensities for the strategies direct and contrarian over all integer values from 0 to 10 . We compared the simulation results with the six variables listed in table 8 . We aimed at simulation results which were between the minimum and maximum experimental results over all twelve sessions of treatment I and II. For each of the 12100 parameter combinations we have run 1000 simulations. There was only one parameter combination which satisfied the requirement of yielding means for the six variables between the minimal and maximal experimentally observed values. This was the parameter combination $(4,3,3,2)$. The numbers refer to main road, side road, direct and contrarian in this order. The parameter 
combination is a reasonable vector of initial propensities. The players know that the capacity of the main road is greater than that of the side road and the first two parameters reflect this knowledge. It is reasonable to suppose that at least in the beginning the simple strategies main road and side road have a greater propensity sum than direct and contrarian.

\begin{tabular}{|l|r|r|r|}
\hline & min Ex I \& II & Simulations & max Ex I \& II \\
\hline mean(\#(players[S])) & 5,85 & 5,88 & 6,17 \\
\hline std_dev(\#(players[S])) & 1,53 & 1,65 & 1,94 \\
\hline mean(\#(road_ch)) & 3,67 & 5,17 & 5,28 \\
\hline mean(\#(last_road_ch)) & 154,78 & 183,73 & 190,39 \\
\hline mean(yule) & 0,12 & 0,14 & 0,37 \\
\hline std_dev(yule) & 0,52 & 0,60 & 0,74 \\
\hline
\end{tabular}

Table 8: Experiments and simulations with 18 players.

It is surprising that a very simple reinforcement model reproduces the experimental data as well as shown by table 8 . Even the mean Yule coefficient is in the experimentally observed range. In spite of the fact that at the beginning of the simulation the behaviour of all simulated players is exactly the same. It is not assumed that there are different types of players. The distribution of the Yule coefficients of the simulated subjects is shown in figure 8. This distribution does not look exactly like the one of the experimentally observed Yule coefficient shown by figure 6 . There are more values in the central range between -.5 and +.5 . However, like in figure 6 , many more observations are in the upper quartile than in the lowest one. This indicates that the direct response mode is much more frequent than the contrarian one, in the experiments as well as in the simulations. 


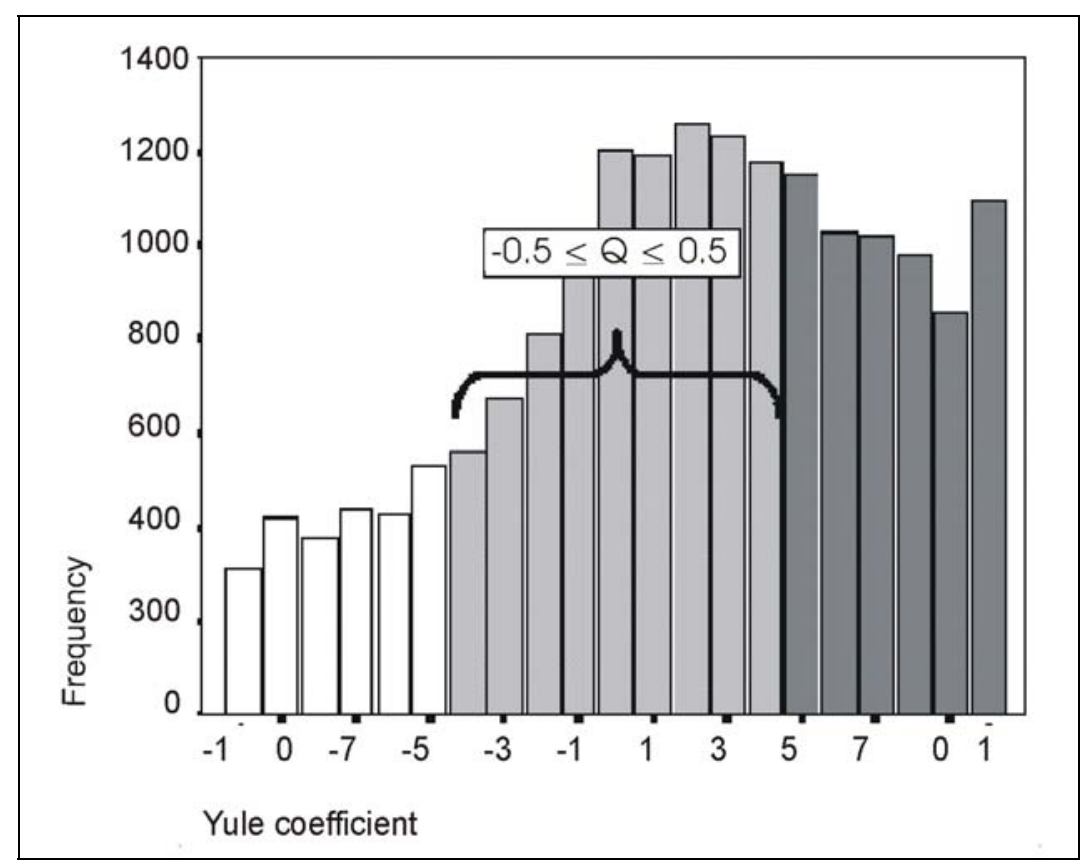

Figure 7: Distribution of the simulated Yule coefficients.

The distribution of the Yule coefficients shown by figure 7 suggests that during the play the behaviour of many simulated players more and more concentrates on one strategy. This is the result of different learning histories.

It is not clear that in the actual experiments tendencies toward direct and contrarian behaviour are mere results of the learning history during the play of the game. Probably some of the experimental subjects bring such tendencies already to the laboratory. This may be due to prior learning outside the laboratory or to inherited behavioural inclinations. We do not want to pass judgement on this but an initial heterogeneity might explain the somewhat smaller concentration 
of the experimental data in the middle range. One could of course try to get an even closer agreement with the experimental data by using a simulation model with subject heterogeneity. However this would involve the estimation of many more parameters.

\section{Conclusion}

The study has shown that the mean numbers on both roads tend to be very near to the equilibrium. Nevertheless, fluctuations persist until the end of the sessions in both treatments. This is of particular interest in view of the fact that the experiments run over 200 periods which is unusually long and should be enough to show a tendency of convergence to equilibrium, if there is one.

Feedback on both road times significantly reduces fluctuations in treatment II compared to treatment I. However the effect is small. There is a significant rank correlation between the total number of road changes and the size of fluctuations. In treatment I road changes may serve the purpose of information gathering. This motivation has no basis in treatment II. However road changes may also be attempts to improve payoffs. The finding of a negative correlation between a subject's payoff and number of road changes suggests that on the average such attempts are not successful. 
Two response modes can be found in the data, a direct one in which road changes follow bad payoffs and a contrarian one in which road changes follow good payoffs. One can understand these response modes as due to different views of the causal structure of the situation. If one expects that the road which is crowded today is likely to be crowded tomorrow one will be in the direct response mode but if one thinks that many people will change to the other road because it was crowded today one has reason to be in the contrarian response mode. We have presented statistical evidence for the importance of the two response modes.

We have also run simulations based on a simple payoff sum reinforcement model. Simulated mean values of six variables have been compared with the experimentally observed minimal and maximal of these variables. The simulated means were always in this range. Only four parameters of the simulation model, the initial propensities, were estimated from the data. In view of the simplicity of the model it is surprising that one obtains a quite close fit to the experimental data. The response modes direct and contrarian also appear in the simulations as the result of an endogenous learning behaviour by which initially homogeneous subjects become differentiated over time. 


\section{References}

ABBINK, K. AND SADRIEH A. 1995: RatImage - Research assistance toolbox for computer-aided human behavior experiments. SFB Discussion Paper B-325, University of Bonn.

ADLER, J. AND BLUE, V., 1998, Toward the design of intelligent traveler information systems, Transpn. Res. C 6, 157.

ARTHUR W., B. 1991: Designing economic agents that act like human agents: A behavioural approach to bounded rationality. Amer. Econ. Rev. Papers Proc. 81 May, 353-359.

Ben-AKIVA, M., DE PALMA, A., KAYSI, I.: 1991, Dynamic network models and driver information systems, Transpn. Res. A 25, 251.

BONSALL, P.: 1992, The influence of route guidance advice on route choice in urban networks, Transportation $19,1-23$.

GigerenZer, G., TODD, P.M. , AND ABC RESEARCH GrouP (eds.), 1999: Simple heuristics that make us smart. Oxford University Press.

HALL, R.: 1996, Route choice and advanced traveler information systems on a capacitated and dynamic network, Transpn. Res. C 4, 289-306.

HARLEY, C. B.: 1981, Learning in Evolutionary Stable Strategie, J. Teoret. Biol. 89, 611-633.

IIDA Y., AKIYAMA T., UCHIDA T.: 1992, Experimental analysis of dynamic route choice behaviour, Trans. Res. 
B 26, 17-32.

RoTH, A.E., EREV, I.: 1995, Learning in extensive form games: Experimental data and simple dynamic models in the intermediate term, Games and economic Behavior 8, $164-212$.

Roth, A.E., EREV, I.: 1998, Predicting how people play games: Reinforcement learning in games with unique mixed strategy equilibrium, American economic review 88, $848-881$.

Wahle, J., Bazzan, A., KlÜGl, F., Schreckenberg, M.: 2000, Decision dynamics in a traffic scenario, Physica A 287, 669-681. 


\section{Appendix}

\section{Leaflet to the traffic experiment}

Altogether 18 persons are participating in this experiment. The game situation is the same for every participant.

The experiment consists of $\mathbf{2 0 0}$ periods.

In each period you are travelling from a starting point $\mathbf{A}$ to an arrival point $\mathbf{B}$. You can either choose a main road or a side road to get from $\mathbf{A}$ to $\mathbf{B}$ (see drawing).

Main road

A

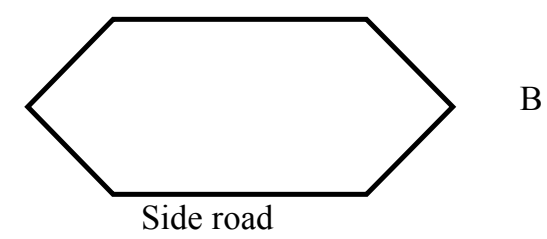

For the travel time from A to B the following holds: On both routes the travel time increases with increasing traffic and decreases with decreasing traffic. If traffic is the same on the main and on the side road, the travel time is shorter on the main road than on the side road.

You can make a new route choice in every period.

Your payoffs per period:

After each period you will receive a period payoff $\mathrm{P}$ which depends on the travel time $\mathrm{T}$. Hereby holds: $\mathrm{P}=40$-T.E.g. the shorter the travel time needed, the higher the payoff.

- $\quad$ Your information per period:

The travel time on the route that you chose in the preceding period

The travel time on the route that you did not choose in the preceding period (only in Experiment II)

Your route chosen in the preceding period.

Your period payoffs in the preceding period in Talers.

Your cumulated payoffs before the route choice in Talers.

Number of the current period.

Each participant receives a seed capital of 200 Talers. The exchange rate is $\mathbf{1 , 5} \mathbf{P f}$ per Taler.

Independent of your success in the game you will receive a 10 DM lump-sum payment for participation. 


\section{Screenshot}

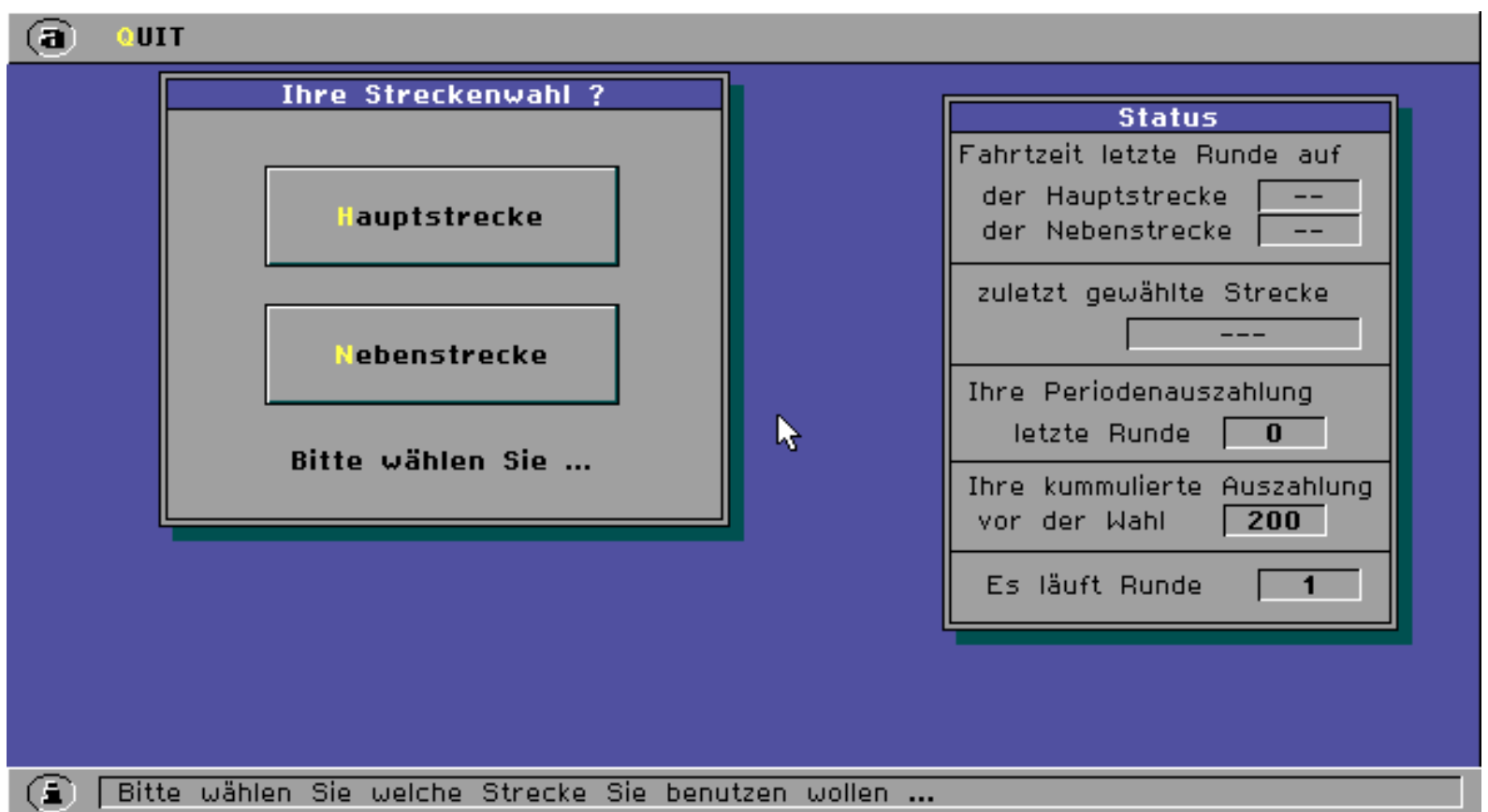

Translation

\begin{tabular}{|l|l|}
\hline \multicolumn{1}{|c|}{ German } & \multicolumn{1}{c|}{ English } \\
\hline Ihre Streckenwahl? & Your route choice? \\
\hline Hauptstrecke & main road \\
\hline Nebenstrecke & side road \\
\hline Bitte wählen Sie... & Please choose... \\
\hline Fahrtzeit letzte Runde auf & travel time in the preceding period on \\
\hline der Hauptstrecke & the main road \\
\hline der Nebenstrecke & the side road \\
\hline zuletzt gewählte Strecke & route chosen in the preceding period \\
\hline Ihre Periodenauszahlung letzte Runde & Your period payoffs in the preceding period \\
\hline Ihre kumulierte Auszahlung vor der Wahl & $\begin{array}{l}\text { Your accumulated payoffs before the route } \\
\text { choice }\end{array}$ \\
\hline Es läuft Runde & This is period \\
\hline
\end{tabular}




\title{
CESifo Working Paper Series
}

\author{
(for full list see www.cesifo.de)
}

833 Gebhard Flaig, Time Series Properties of the German Monthly Production Index, January 2003

834 Campbell Leith and Jim Malley, Estimated Open Economy New Keynesian Phillips Curves for the G7, January 2003

835 Burkhard Heer and Bernd Süssmuth, Inflation and Wealth Distribution, January 2003

836 Erkki Koskela and Leopold von Thadden, Optimal Factor Taxation under Wage Bargaining - A Dynamic Perspective, January 2003

837 Carola Grün and Stephan Klasen, Growth, Income Distribution, and Well-Being: Comparisons across Space and Time, January 2003

838 Robert S. Chirinko and Ulf von Kalckreuth, On the German Monetary Transmission Mechanism: Interest Rate and Credit Channels for Investment Spending, January 2003

839 Sascha O. Becker, Andrea Ichino, and Giovanni Peri, How Large is the "Brain Drain" from Italy?", January 2003

840 Albert Berry and John Serieux, All About the Giants: Probing the Influences on Growth and Income Inequality at the End of the $20^{\text {th }}$ Century, January 2003

841 Robert Fenge and Martin Werding, Ageing and the Tax Implied in Public Pension Schemes: Simulations for Selected OECD Countries, January 2003

842 Robert Fenge and Martin Werding, Ageing and Fiscal Imbalances Across Generations: Concepts of Measurement, January 2003

843 Giovanni Andrea Cornia, The Impact of Liberalisation and Globalisation on Income Inequality in Developing and Transitional Economies, January 2003

844 Peter Fredriksson and Per Johansson, Program Evaluation and Random Program Starts, January 2003

845 Bernd Hayo and Matthias Wrede, Fiscal Equalisation: Principles and an Application to the European Union, January 2003

846 Syed M. Ahsan and Jaideep Oberoi, Inequality, Well-being and Institutions in Latin America and the Caribbean, January 2003

847 Chang Woon Nam and Doina Maria Radulescu, The Role of Tax Depreciation for Investment Decisions: A Comparison of European Transition Countries, January 2003 
848 V. Bhaskar and Steinar Holden, Wage Differentiation via Subsidised General Training, January 2003

849 Paloma Lopez-Garcia, Labour Market Performance and Start-up Costs: OECD Evidence, January 2003

850 Christian Keuschnigg and Soren Bo Nielsen, Public Policy for Start-up Entrepreneurship with Venture Capital and Bank Finance, January 2003

851 Yin-Wong Cheung, Menzie D. Chinn, and Eiji Fujii, China, Hong Kong, and Taiwan: A Quantitative Assessment of Real and Financial Integration, January 2003

852 Gregory D. Hess, The Economic Welfare Cost of Conflict: An Empirical Assessment, February 2003

853 Douglas J. Cumming and Jeffrey G. MacIntosh, Comparative Venture Capital Governance. Private versus Labour Sponsored Venture Capital Funds, February 2003

854 Eckhard Janeba and John Douglas Wilson, Decentralization and International Tax Competition, February 2003

855 Tapio Palokangas, Capital Accumulation and Employment Cycles in a Model of Creative Destruction, February 2003

856 Brendan Walsh, When Unemployment Disappears: Ireland in the 1990s, February 2003

857 Luis H. R. Alvarez and Erkki Koskela, A General Approach to the Stochastic Rotation Problem with Amenity Valuation, February 2003

858 Christian Schultz, Strategic Campaigns and Redistributive Politics, February 2003

859 Ernst Fehr and Joseph Henrich, Is Strong Reciprocity a Maladaptation? On the Evolutionary Foundations of Human Altruism, February 2003

860 Haizhou Huang, Dalia Marin, and Chenggang Xu, Financial Crisis, Economic Recovery and Banking Development in Former Soviet Union Economies, February 2003

861 Pedro Cardoso and Bernard M.S. van Praag, How Sustainable Are Old-age Pensions in a Shrinking Population with Endogenous Labour Supply?, February 2003

862 Volker Meier, Efficient Transfer of Aging Provisions in Private Health Insurance, February 2003

863 Edward Castronova, Theory of the Avatar, February 2003

864 Robert S. Chirinko, Hans van Ees, Harry Garretsen, and Elmer Sterken, Investor Protections and Concentrated Ownership: Assessing Corporate Control Mechanisms in the Netherlands, February 2003

865 Bernard M.S. van Praag and Pedro Cardoso, The Mix Between Pay-as-you-go and Funded Pensions and what Demography has to do with it, February 2003 
866 Ernst Fehr, Urs Fischbacher, Bernhard von Rosenbladt, Jürgen Schupp, and Gert G. Wagner, A Nation-Wide Laboratory. Examining Trust and Trustworthiness by Integrating Behavioral Experiments into Representative Survey, February 2003

867 Frank Heinemann, The Inflationary Impact of Wage Indexation, February 2003

868 Eytan Sheshinski, Bounded Rationality and Socially Optimal Limits on Choice in a Self-Selection Model, February 2003

869 M. Hashem Pesaran, Estimation and Inference in Large Heterogenous Panels with Cross Section Dependence, February 2003

870 Luis H. R. Alvarez and Erkki Koskela, On the Tree-Cutting Problem under Interest Rate and Forest Value Uncertainty, February 2003

871 Norbert Berthold and Rainer Fehn, Unemployment in Germany: Reasons and Remedies, February 2003

872 Clemens Fuest, Bernd Huber, and Philipp Tilleßen, Tax Policy and Entrepreneurship in the Presence of Asymmetric Information in Capital Markets, February 2003

873 Eytan Sheshinski, Optimum and Risk-Class Pricing of Annuities, February 2003

874 Willi Leibfritz, Paul O'Brien and Jean-Christophe Dumont, Effects of Immigration on Labour Markets and Government Budgets - An Overview, February 2003

875 M. Hashem Pesaran and Allan Timmermann, How Costly is it to Ignore Breaks when Forecasting the Direction of a Time Series?, February 2003

876 Thorvaldur Gylfason and Gylfi Zoega, Education, Social Equality and Economic Growth: A View of the Landscape, February 2003

877 Robin Boadway and Jean-François Tremblay, Public Economics and Startup Entrepreneurs, February 2003

878 Erkki Koskela and Roope Uusitalo, The Un-Intended Convergence: How the Finnish Unemployment Reached the European Level, February 2003

879 Robert Fenge and Volker Meier, Pensions and Fertility Incentives, February 2003

880 Eytan Sheshinski, Note on Income Taxation and Occupational Choice, February 2003

881 A B Atkinson, Income Inequality in OECD Countries: Data and Explanations, February 2003

882 Thomas Gehrig and Rune Stenbacka, Venture Cycles: Theory and Evidence, February 2003

883 Ralf Becker and Thomas Hellmann, The Genesis of Venture Capital - Lessons from the German Experience, March 2003 
884 Eytan Sheshinski, Note on the Optimum Pricing of Annuities, March 2003

885 Paul De Grauwe and Magdalena Polan, Globalisation and Social Spending, March 2003

886 F. van der Ploeg, Do Social Policies Harm Employment and Growth?, March 2003

887 Mirjam van Praag, Initial Capital Constraints Hinder Entrepreneurial Venture Performance: An empirical analysis, March 2003

888 Bernard Steunenberg, Coordinating Sectoral Policymaking: Searching for Countervailing Mechanisms in the EU Legislative Process, March 2003

889 Eytan Sheshinski, Optimum Delayed Retirement Credit, March 2003

890 Frederick van der Ploeg, Rolling Back the Public Sector - Differential effects on employment, investment and growth, March 2003

891 Paul De Grauwe and Marc-Alexandre Sénégas, Monetary Policy in EMU when the Transmission is Asymmetric and Uncertain, March 2003

892 Steffen Huck and Kai A. Konrad, Strategic Trade Policy and the Home Bias in Firm Ownership Structure, March 2003

893 Harry Flam, Turkey and the EU: Politics and Economics of Accession, March 2003

894 Mathias Hoffmann and Ronald MacDonald, A Re-examination of the Link between Real Exchange Rates and Real Interest Rate Differentials, March 2003

895 Badi H. Baltagi, Espen Bratberg, and Tor Helge Holmås, A Panel Data Study of Physicians' Labor Supply: The Case of Norway, March 2003

896 Dennis C. Mueller, Rights and Citizenship in the European Union, March 2003

897 Jeremy Edwards, Gains from Trade in Tax Revenue and the Efficiency Case for Trade Taxes, March 2003

898 Rainer Fehn and Thomas Fuchs, Capital Market Institutions and Venture Capital: Do They Affect Unemployment and Labour Demand?, March 2003

899 Ronald MacDonald and Cezary Wójcik, Catching Up: The Role of Demand, Supply and Regulated Price Effects on the Real Exchange Rates of Four Accession Countries, March 2003

900 R. Selten, M. Schreckenberg, T. Pitz, T. Chmura, and S. Kube, Experiments and Simulations on Day-to-Day Route Choice-Behaviour, April 2003 